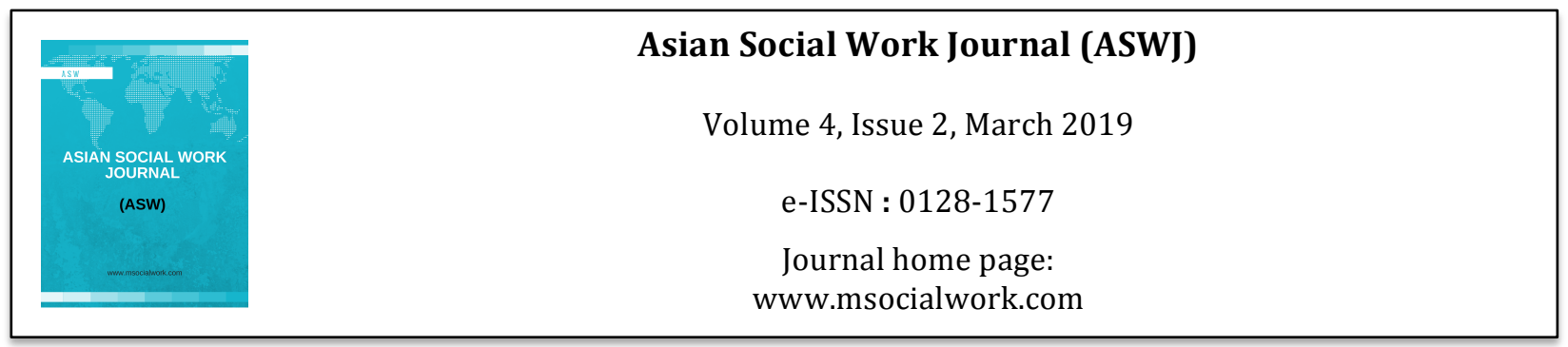

\title{
Community Participation in Maintenance of Environment Corporate Social Responsibility (CSR) PT. Pegadaian Region X Bandung
}

\author{
Riany Laila Nurwulan ${ }^{1}$, Nina Kurniasih ${ }^{1}$, HR. Sumardhani ${ }^{1}$ \\ 1Pasundan University, Bandung, Indonesia \\ Corrrespondence: Riany Laila Nurwulan (Riany.lailanurwulan@unpas.ac.id)
}

\begin{abstract}
This research has produced a model of three-pillar cooperation between government - private community in the implementation of an activity for development. The government as a regulator issues development programs that aim to improve the welfare of the community, including development in the environmental field. Sustainable environment has an impact on comfort and public health. Not all of these programs are covered by the government due to government budget constraints. Therefore, in order for programs to be implemented it is necessary to have cooperation with the private sector, especially business entities in the form of limited liability companies, as stated in Law no. 40/2007 concerning Limited Liability Company article 74. In this case utilizing funds from a corporate social responsibility (CSR) program. Companies in the form of State-Owned Enterprises (BUMN) put them in the Partnership and Community Development Program (PKBL), including PT. Pegadaian. The statement of the problem in this study is that the need for community participation in environmental preservation. The study used qualitative methods with in-depth interview and observation data collection techniques. Data triangulation is used to complement data analysis. PT. Pegadaian Region X in the Pungkur Region realized the Environmental Development program in the environment in the Balonggede Sub-District of Regol Sub-District in 2016, namely planting ornamental plants in pots (red shoots) along the sidewalks of the Pungkur road and the Dalem Kaum road for approximately 80 units. After being handed over to the government of the Balonggede Village, its maintenance is the responsibility of the Balonggede Village by involving the surrounding community, especially the people who are close to or in contact with the object. The diversity of people's treatment of plants reflects different perceptions resulting in plants that are not in uniform growth conditions, some are well maintained and grow well, and some are in poor growth conditions. This shows a lack of ownership of public facilities, thus indicating a low level of community participation in environmental preservation, especially environmental facilities as asistance of PT. Pegadaian Region X.
\end{abstract}

Key words: three pillar cooperation, environmental CSR, community participation

\section{Introduction}

Since the enactment of Law No. 40/2007, many companies have implemented corporate social responsibility programs, especially large companies, such as those carried out by multinational companies, state-owned companies, mining companies, and other private companies. Thus the contribution of the business world through corporate social responsibility programs in caring for the environment in Indonesia is quite large, including concern for environmental issues. Based on a study of the results of the research Florencia et all, the environmental CSR program in five-star hotels in Ubud Tourism Area has not been effective. Of the seven Environmental CSR programs that have been 
implemented, only two programs have been effective, namely Climate Change Adaptation and Environmental Education (PLH), while the other five programs have not run effectively are Clean Production, Eco-Friendly Office (Eco Office), Waste Management with the 3R Principles (Reduce, Reuse and Recycle), Conservation of Natural Resources and Energy, and Renewable Energy Program ${ }^{1}$. While the results of Alfitri et.al's research suggest that environmental social responsibility in the program to improve the quality of environmental health and the resulting natural conservation program is considered to be less than optimal, because the implementation is carried out incidentally only based on community ${ }^{2}$.

Regarding the community, the results of Stephanus's research show that the lack of community participation in corporate social responsibility programs is due to the negative perception of the company PT. Holcim, especially in the environmental field, shows very poor perceptions ${ }^{3}$. From the results of the above research, it appears that the tendency to implement corporate social responsibility is more oriented to incidental activities. This is as revealed by Suharto (2009) that corporate social responsibility is still "kiss and run". Several studies related to corporate social responsibility in its implementation showed success and failure. However, these studies have provided knowledge for researchers to carry out further research, especially regarding corporate social responsibility that carries out its activities in the environmental field so that it has a positive impact on environmental sustainability. Therefore the study to be carried out is considered to have an important aspect, namely the aspect of community participation in the implementation of corporate social responsibility in the field of environment which can be used as a reference for other companies that implement it. In this regard, the Bandung city government is actively promoting environmental management, including by trotoarization, building several city parks, and making flower plants in pots (tabulampot) which are spread throughout almost the entire city of Bandung. So that adds to the beauty and attractiveness of the city of Bandung.

In its implementation, the government cannot cover all programs related to the environment. Therefore the government cooperates with companies, as in the city of Bandung. This is contained in the Regional Regulation of Bandung City Number 13 of 2012 concerning the Implementation of the Obligation of Corporate Social and Environmental Responsibility Programs. Article 5 (1) stipulates that every company domiciled in the region must implement the TJSL program, based on the provisions of the legislation. This is so that all programs are implemented properly. So that research on cooperation between the government and the business world in the field of environment that requires community participation in its maintenance is important, with the theme "Community Participation in the Maintenance of Environmental CSR Assistance" One company that carries out social responsibility in the field of environment is PT. Pegadaian Wilayah X, Bandung City, which provides assistance in plants in pots along the sidewalks of Pungkur.

Indeed the purpose of the aid is to preserve the environment and the beauty of the face of the city of Bandung. But based on observations, the conditions of the results of these activities appear to be poorly

\footnotetext{
${ }^{1}$ Efektivitas Program Corporate Social Responsibility (Csr) Bidang Lingkungan Hidup Pada Hotel Bintang Lima Di Kawasan Pariwisata Ubud, Kabupaten Gianyar, Olivia Grace Brigitta Florencia1*), Made Sudiana Mahendra 2), I Wayan Arthana 3)

1)Program Magister Ilmu Lingkungan Universitas Udayana

2)Fakultas Pertanian Universitas Udayana

3)Fakultas Kelautan Dan Perikanan Universitas Udayana

2 C 2015 Program Studi Ilmu Lingkungan Program Pascasarjana Undip

Jurnal Ilmu Lingkungan; Implementasi Program Csr Lingkungan Pt. Semen Baturaja (Persero) Tbk Terhadap Kondisi Sosial Ekonomi Masyarakat Di Kabupaten Ogan Komering Ulu Sumatera Selatan, Enda Kartika Sari1, Andy Mulyana2, Alfitri3

1 Program Studi Pengelolaan Lingkungan, Program Pascasarjana, Universitas Sriwijaya (E-Mail:

Endah_Ubr@Ymail.Com)

2 Program Studi Agribisnis, Fakultas Pertanian, Universitas Sriwijaya

3 Jurusan Sosiologi, Fakultas Ilmu Sosial Dan Ilmu Politik, Universitas Sriwijaya

${ }^{3}$ Persepsi Masyarakat Terhadap Partisipasi Mereka Dalam Program Csr Pt Holcim Indonesia Tbk Cilacap Plant, Stephanus / Susanto Program Studi Sosiologi Fakultas Ilmu Sosial Dan Politik Universitas Atma Jaya Yogyakarta
} 
maintained, do not grow well, and abuse the function of the community. The researcher estimates that there is a need for local community participation in maintaining the assistance.

\section{Literature Review}

The government has a responsibility to overcome social and environmental problems. Because the government has limitations in handling it, it is necessary to hold the business world to work together. The business world realizes it through corporate social responsibility (CSR). John Elkington (1998) in his book "Canibals with Forks: The Triple Bottom Line in 21st Century Business" written by Suharto argues that conceptually corporate social responsibility is a corporate concern based on three basic principles known as Triple Bottom Lines (3P) : 1. Profit; that the company still has to be oriented to seek economic benefits that enable the company to continue to operate and develop. So that the company in addition to carrying out its financial obligations can also set aside profits for activities in corporate social responsibility programs. 2. People; is a community where the company is located where the company must have concern for the welfare of its people. 3. Planet; is the physical environment of the company, where the company cares about the environment and the sustainability of biodiversity so that environmental damage can be prevented (2010:5)

That the company has an obligation to set aside part of its profits for the benefit of the community, in handling social and environmental problems.

In addition to being the responsibility of the government and the business community in dealing with social and environmental problems, cooperation with the community is also needed so that the community can participate or participate specifically in environmental care. Keith Davis in Sastropoetro (1988) suggests several types of community participation, which include participation:

$\begin{aligned} \text { i. } & \text { Mind } \\ \text { ii. } & \text { Power } \\ \text { iii. } & \text { Expertise } \\ \text { iv. } & \text { Goods } \\ \text { v. } & \text { Money. }\end{aligned}$

In relation to these concepts, Julimawati (2015) in her research results suggested that the community has the motivation to maintain / improve the quality of the neighborhoods. High motivation is realized in the form of actions to improve and maintain the environment. This high motivation is also supported by the participation in the form of funds, labor and infrastructure. Perceptions of environmental quality are known to be a trigger for motivation in improving environmental quality ${ }^{4}$.

\section{Research methods}

This study was designed based on a qualitative descriptive approach with a case study method that aims to sharpen the characteristics and symptoms studied regarding social phenomena as they relate to government cooperation - the business world and society through the implementation of corporate social responsibility in the environment in Balonggede Village Regol District, Bandung City . Sources of data serve as informants, namely people who know and have complete information and understand the problem under study. The informants were determined purposively, based on the consideration that the actors of the chosen corporate social responsibility activities had the information needed in the research and the willingness of the concerned to become informants. The data sources are: 1. Head of PKBL Division of PT. Pegadaian 2. Balonggede Village Government 3. Communities around the company's assistance location

\footnotetext{
${ }^{4}$ Julimawati (2015), Partisipasi Masyarakat Dalam Menjaga Kualitas Lingkungan Permukiman Di Kecamatan Baleendah, JPIS, Jurnal Pendidikan Ilmu Sosial, Vol. 24, No. 2, Edisi Desember 2015
} 
Data collection techniques used are as stated by Creswell (2010: 268), namely observation, interviews, documentation studies, and audio visual. Data analysis is carried out qualitatively through a systematic process in which the implementation has begun since data collection and has been done more carefully, both since or during the field and after no longer being in the field, The research was conducted in Balonggede Sub-District, Regol District, Bandung City. The reason for taking the location is that Balonggede Village is one of the regions that received the Bandung City structuring program as well as the target area for recipients of environmental CSR assistance.

\section{Research result}

\section{Implementation of Corporate Social Responsibility (CSR) of PT. Pegadaian}

Since 2013, the Bandung City Government has been actively working on structuring the city with the construction of various parks in every corner of the city, that is, since the Bandung City government was led by M. Ridwan Kamil. "Since being installed as mayor in 2013, he made a breakthrough by reviving city parks, giving fines to smokers in public places, ..." (http: //www.bbc.com.indonesia/special report, July 27,2014$)$. This is intended so that the corners of the city are protected from the sight that looks slum as well as aims to facilitate the citizens of the community for the needs of recreational places that are easily accessible to the community.

$\operatorname{Huraerah}^{5}$ (2018) suggests that the function of city parks in ecosystems plays an important role, as a counterweight to ecosystems for environments that have had many changes in urban areas. The function of trees and greenery in city parks is needed to filter out pollution originating from motor vehicle exhaust The Balonggede sub-district is one of the sub-districts for the agenda, and is instructed to arrange the area along Jalan Balonggede and the surrounding areas including a park. To carry out the agenda, the Balonggede Village Government did not have enough funds. Therefore the Kelurahan received assistance from the City Government. In addition, the Kelurahan cooperates with several companies located in the Balonggede Village to realize the program. Companies involved include PT. Pegadaian, Kings Shoping Center, Teh Botol Sosro, and other companies. For structuring the sidewalks along the Pungkur road and Jalan Dalem Kaum, requests for assistance were submitted to PT. Pegadaian in 2016 in the context of structuring the environment in the Balonggede region, which is also associated with the Bandung city government program for City planning. The realization of PT. Pegadaian CSR in the field of social and environmental development is carried out through the implementation of the Partnership and Community Development Program (PKBL), as stipulated in the Regulation of the State Minister for State-Owned Enterprises No. PER-08 / MBU / 2013, the last one was changed to No. PER-09 / MBU / 07/2015 concerning the State-Owned Enterprises' Partnership Program and Community Development Program. One of the objectives of the community development program is to provide assistance in the environmental field to help preserve nature. In the Balonggede Village of PT Pegadaian, Region X realized the Community Development program through the provision of plants (trees) in pots along the sidewalks of Jalan Pungkur and Jalan Dalem Kaum which numbered approximately 80 pots as requested by the Government of the Balonggede Village. Companies through the Partnership and Community Development Program (PKBL) field responded to the submission of applications within 1 (one) month with realization through third parties, namely assistance provided in the form of goods and work, namely the installation of red shoots along Pungkur road, and maintenance. The work contract is carried out for one month which includes all material needs, workmanship and risks that occur in the implementation of such assistance, such as damage to pots, damaged or dead plants, third parties must replace them. After passing a one month contract period, the maintenance is the responsibility of the kelurahan as the recipient of assistance. Among them are activities of watering, fertilizing, structuring, and maintaining. For this assistance, the Balonggede village government created a maintenance agenda, including regular watering twice a week by village officials, carrying out the Thursday program along the Pungkur road, and dismissing street vendors along the Pungkur road sidewalk, to arrange the area in question.

\footnotetext{
${ }^{5}$ Model inovasi Pelayanan di Rumah Sakit, FISIP Unuiversitas Pasundan, 2018
} 
The kelurahan through the local RT / RW appealed to residents along the Pungkur road to participate in maintaining potted plants along the sidewalks of both plants originating from the village and from PT. Pegadaian. B. Community Participation In addition to being carried out by the local government, environmental maintenance in the Balonggede Urban Village also called on the community to participate, including their participation in the maintenance of plants as assistance from PT. Pegadaian. For the maintenance of assistance, participation from the community is needed, especially for the people who live near the place / aid located. Given the importance of maintaining plants is very necessary for beauty and environmental health. Therefore it is necessary for the participation of the community to maintain it. The population of the Balonggede Village is a heterogeneous society, consisting of indigenous people and immigrants. The migrants are residents from outside the region, both indigenous and non-indigenous. Most of the residents living along the Pungkur road are mostly non-indigenous residents with commercial livelihoods, namely selling vehicles, vehicle spare parts, stationery, electrical equipment, and opening workshops. Because the assistance is installed along the highway, the nearby community in question is a community of shop owners and traders along the road where the pot is installed. Mind Fruit Participation; The participation of ideas is participation in the form of suggestions, ideas, ideas, or other ideas. The thoughts in this matter are the thoughts of the citizens of the assistance received from PT. Pegadaian Regional X, as the realization of the community development program. Reality in the field based on the results of the study shows that community participation in environmental preservation in the form of ideas is divided into two perceptions:

i. The community perceives that the assistance provided by PT. Pegadaian is the responsibility of citizens. Therefore the community has a sense of belonging for the assistance received.

ii. The community perceives that the assistance provided by PT. Pegadaian is not the responsibility of citizens. So that the community thinks that there is no obligation for him to participate in preserving the environment

\section{Energy participation}

Participation in the form of labor provided is an activity carried out on assistance received, both activities of watering, fertilizing, arranging or other treatments related to plant maintenance. Some people routinely water the plants located in front of their shops. Watering is carried out every morning along with washing vehicles. Watering is done by workers at the store as a sense of belonging and responsibility for the appeal of the local village. The participation of workers provided by other residents is in the form of watering their own routine activities on the plants by using the remaining water from meat washing as well as in order to use the water. According to him, washing water used to function as fertilizer, watering plants can thrive. Residents took the initiative to water the plants not only in front of the shop but also to the plants located at the end of the pungkur road, there were approximately 5 (five) plants. The participation of workers in maintaining the environment in other forms is done by cleaning the plant pots to be free from garbage. Some people treat plant pots as garbage dumps, both household and domestic waste. This is mostly done by the community of shop traders, street vendors and pedestrians. The plant pot located on the sidewalk where the car service workshop is located is often used as a dumping place for used oil or packaged garbage. While pedestrians often when passing waste wrapping food or cigarette butts.

\section{Expertise Participation}

Participation of expertise is interpreted as creativity by giving certain treatments, namely cutting the tops of plants so that the plants do not grow bigger but grow well and form bonsay plants. Use plant pots to serve as a table for storing food and drinks. The effect of the plants being maintained and growing well. Another skill participation is farming by planting other crops (intercropping) around the staple plants, namely by planting pandan leaves and chili trees. This is done because the informant argues that it is better to cultivate which is beneficial than overgrown with weeds. So the informants felt that they had a sense of belonging to the plant. Meanwhile the plants in the pot are used by other traders to be used as the back of the tent where they sell food. From this treatment the plant becomes neglected and damaged. This is partly due to public indifference to plant growth. 


\section{Participation in the form of goods / money}

Participation can be done in the form of material, both goods and money, to support a program so that the program runs as expected. In-kind participation is carried out by informants as the responsibility for damage to plant pots due to their negligence. As for participation in the form of money, it is given to the local RT as a contribution / contribution for the maintenance of the local environment, not only for plant assistance, but also for other environmental maintenance. The community does not feel objected to the material assistance provided, because the community understands that this is for the smooth running of the activities carried out.

\section{Conclusion}

Based on the results of these studies it can be concluded as follows: Government cooperation with the business world in this case Balonggede Village with PT. Pegadaian Region X in the environmental field was realized through the Community Development program in the form of assistance activities in potted plants along Jalan Pungkur and Jalan Dalem Kaum.

Efforts to maintain assistance require support from the community in the form of participation in maintenance, which includes participation. Mind, Power, Expertise, Goods, and money participation, both in watering, fertilizing, controlling pest (plant pest organisms) and structuring.

Community participation in environmental preservation in Balonggede Village is motivated by their sense of belonging to the assistance provided by PT. Pegadaian. When people have a sense of belonging, their participation in maintaining the environment is good, while the people who lack a sense of belonging do not show good participation.

\section{References}

Creswell, J.W. (2010), Research design: pendekatan kualitatif, kuantitatif, dan mixed, PT Pustaka Pelajar, Yogjakarta

Dwi Kartini, (2009). Corporate Social Responsibility, Transformasi konsep Sustainability Management Dan Implementasi Di Indonesia, Refika Aditama, Bandung.

Elkington, John (1998), Cannibals With Forks: The Triple Bottom Line in 21st Century Business, Gabriola Island, BC: New Society Publishers

Enda Kartika Sari, Andy Mulyana, Alfitri, Jurnal Ilmu Lingkungan; Implementasi Program Csr Lingkungan Pt. Semen Baturaja (Persero) Tbk Terhadap Kondisi Sosial Ekonomi Masyarakat Di Kabupaten Ogan Komering Ulu Sumatera Selatan, Universitas Sriwijaya

Huraerah, Abu, (2018). Model Inovasi Pelayanan Kesehatan di Rumah Sakit, FISIP UNPAS,Bandung Ife, Jim (2008). Community Development Alternatif Community Development Di Era Globalisasi. Pustaka Pelajar, Yogyakarta

Isbandi Rukminto Adi. (2007). Perencanaan Partisipatoris Berbasis Aset Komunitas: dari Pemikiran Menuju Penerapan. Depok: FISIP UI Press.

Junaidi, Muhammad, (2013). Korporasi Dan Pembangunan Berkelanjutan, Alfabeta, Bandung

Kementrian Lingkungan Hidup, Pedoman CSR Bidang Lingkungan

Kenny, Susan, (2007). Developing Communities For The Future, Thompson, South Melbourne

Mitchell, Bruce et.al, (2003). Pengelolaan Sumber Daya Dan Lingkungan, Gadjah Mada University Press, Yogyakarta

Moleong, Lexy J, (1994). Metodologi Penelitian Kualitatif, Remaja Rosdakarya, Bandung.

Norhadi, (2011). Corporate Social Responsibility, Graha Ilmu, Semarang

Olivia Grace Brigitta Florencia, Made Sudiana Mahendra, I Wayan Arthana, Efektivitas Program Corporate Social Responsibility (Csr) Bidang Lingkungan Hidup Pada Hotel Bintang Lima Di Kawasan Pariwisata Ubud, Kabupaten Gianyar, Universitas Udayana

Rudito Bambang, (2013). CSR (Corporate Social Responsibility, Rekayasa Sains, Bandung Soedarmayanti, (2012). Good Governance \& Good Corporate Governance, Mandar Maju, Bandung 
Soemarwoto, Otto, (1994). Ekologi, Lingkungan Hidup, Dan pembangunan, Djambatan, Bandung Soemarwoto, Otto, (2001). Analisis Mengenai Dampak Lingkungan, Gadjah Mada University Press, Yogyakarta

Stephanus / Susanto, Persepsi Masyarakat Terhadap Partisipasi Mereka Dalam Program Csr Pt Holcim Indonesia Tbk - Cilacap Plant, Program Studi Sosiologi Fakultas Ilmu Sosial Dan Politik Universitas Atma Jaya Yogyakarta

Suharto, Edi (2009). Pekerjaan Sosial Di Dunia Industri, Alfabeta, Bandung

Suharto, Edi (2010). CSR \& Comdev Investasi Kreatif Perusahaan Di Era Globalisasi, Alfabeta, Bandung

Suharto, Edi, (2007). Kebijakan Sosial sebagai Kebijakan Publik, Alfabeta Bandung.

Sunyoto Usman, 1998, Pembangunan Dan Pemberdayaan Masyarakat, Pustaka Pelajar, Yogyakarta.

Supardi, 1994, Lingkungan hidup dan Kelestariannya, Alumni, Bandung

Wahyudi, Isa et.al, (2011). Corporate Social Responsibility : Prinsip, Pengaturan \& Implementasi, Setara Press \& Inspire, Malang 